\title{
Efficacy of heterologous and homologous heat shock protein 70s as protective agents to Artemia franciscana challenged with Vibrio campbellii
}

\author{
Kartik Baruah, Jayant Ranjan, Patrick Sorgeloos, Peter Bossier* \\ Laboratory of Aquaculture and Artemia Reference Center, Faculty of Bioscience Engineering, Ghent University, Rozier 44, 9000 Ghent, Belgium
}

\section{A R T I C L E I N F O}

\section{Article history:}

Received 10 April 2010

Received in revised form

28 June 2010

Accepted 2 July 2010

Available online 17 July 2010

\section{Keywords:}

Heat shock protein (Hsp) 70

DnaK

Phenoloxidase

Artemia franciscana

Vibrio campbellii

\section{Introduction}

Diseases caused by pathogenic or opportunistic bacteria, such as Vibrio spp. are still considered a major constraint to the sustainable development of aquaculture worldwide [1]. Although, the use of antibiotics and disinfectants had some success in the prevention or cure of such diseases [2], such practices are undesirable as they promote the selection and dissemination of antibiotic-resistant bacteria in both the target organisms, as well as in the environment [3]. Therefore, the use of alternative control approaches is becoming increasingly important for further development of more sustainable aquaculture practices.

In recent years, heat shock proteins (Hsps) have received considerable attention owing to their multi-functional features $[4,5]$. They are soluble intracellular chaperones present in all organisms from prokaryotes to eukaryotes [6,7]. Most Hsps are constitutively expressed under normal physiological conditions, however, their expression is up-regulated by various physiological stressors, such as high temperature, toxins, osmotic stress, ultraviolet and gamma radiation, certain chemicals and drugs, hypoxia,

\footnotetext{
* Corresponding author. Tel.: +32 926 43754; fax: +32 92644193.

E-mail address: peter.bossier@ugent.be (P. Bossier).
}

glucose deprivation, and microbial infection that could potentially damage the cellular and molecular structures in the cells [8,9]. Hsps perform essential biological functions under both normal and stressful conditions such as assisting in the folding of nascent proteins, translocation of these proteins between cell organelles, assembly and disassembly of multi-subunit complexes, refolding or degradation of denatured proteins due to stresses, dissolution of pathological protein aggregates, and other processes enhancing the survival of normal and diseased cells and tissues [10].

Evidence from several studies suggested that Hsps, particularly those of the Hsp70 family, can mediate the generation of strong innate and adaptive immune responses against many diseases $[6,7,11]$, leading to the formulation of strategies to fight infections. Recently, our laboratory has explored the hypothesis that Hsps control disease in aquaculture and found that induction of Hsp in Artemia (eukaryotic Hsp70) through a non-lethal heat shock is associated with protection against virulent Vibrios [12]. In another study [13], the same authors observed that ingestion of Escherichia coli overproducing DnaK (prokaryotic equivalent to Hsp70) significantly improved the survival of gnotobiotically cultured Artemia upon challenge with $V$. campbellii. These studies suggest that Hsp70 (either prokaryotic or eukaryotic) conferred protection to Vibriochallenged Artemia. The Hsp70 family members derived either from the prokaryotes or eukaryotes have a high degree of sequence 
homology (about 60\%), and there is a possibility that all Hsp70 proteins, irrespective of source, might have the same basic biological activity [14], especially in relation to their protective properties against bacterial infection. However, this hypothesis remains controversial as evidence from several studies, particularly in vitro, suggested that Hsp of the same family, but from different species, might have markedly different activity [15-17].

This study was set up to verify the hypothesis that feeding Artemia with E. coli overproducing homologous Artemia Hsp70 would equally well protect Artemia against the pathogen Vibrio campbellii as through feeding E. coli overproducing heterologous DnaK.

\section{Materials and methods}

\subsection{PCR amplification and cloning of Artemia Hsp70 and bacterial DnaK genes}

Artemia Hsp70 cDNA, a generous gift from Dr. Thomas $\mathrm{H}$. MacRae, Department of Biology, Dalhousie University, Canada, was amplified by polymerase chain reaction and cloned into the $\mathrm{TOPO}^{\circledR}$ cloning vector using a pBAD Directional TOPO $^{\circledR}$ Expression Kit (Invitrogen $^{\mathrm{TM}}$, Merelbeke, Belgium) according to manufacturer recommendations. PCR reaction was performed in a $50 \mu \mathrm{l}$ reaction mixtures containing $1 \mu \mathrm{l}$ cDNA as template, $2 \mathrm{mM}$ of $\mathrm{MgSO}_{4}, 0.2 \mathrm{mM}$ of dNTP mix, 1.25 unit of proofreading pfu DNA polymerase (Fermentas), $1 \times p f u$ buffer, and $1 \mu \mathrm{M}$ each of oligonucleotide primers Artemia Hsp70 forward $^{\prime}$ - CACCATGGCAAAGGCACCAGCAATAGG-3' and Hsp70 $0_{\text {reverse }} 5^{\prime}$ - ATAGTTGGGCCACTGCCTGTTCCAG-3'. PCR conditions were as follows: denaturation at $94^{\circ} \mathrm{C}$ for 5 min followed by 35 cycles of $95{ }^{\circ} \mathrm{C}$ for $1 \mathrm{~min}$, annealing at $50{ }^{\circ} \mathrm{C}$ for $1 \mathrm{~min}$ and extension at $72{ }^{\circ} \mathrm{C}$ for $2 \mathrm{~min}$ followed by $10 \mathrm{~min}$ at $72{ }^{\circ} \mathrm{C}$. Amplification of the appropriate 1935 base pairs fragment was verified by electrophoresis. It was then ligated into the TOPO cloning vector and transformed into One Shot TOP10 (non-pathogenic E. coli) cells, which were grown on Luria-Bertani (LB) agar containing $100 \mu \mathrm{g} \mathrm{ml}^{-1}$ ampicillin at $37^{\circ} \mathrm{C}$. A bacterial clone containing Artemia Hsp70 cDNA was isolated from the LB plate, labelled $A_{\text {native, and }}$ stored in $40 \%$ glycerol at $-80^{\circ} \mathrm{C}$.

Strains YS2 (which expresses the 70-kDa bacterial Hsp, DnaK, upon arabinose induction) and YS1 (which does not express DnaK upon arabinose induction) were described previously [13].

\subsection{Induction of Hsp70 proteins in E. coli strains}

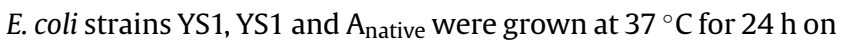
LB agar and then to log phase in LB broth by incubation at $37^{\circ} \mathrm{C}$. V. campbellii strain LMG 21363 stored in $40 \%$ glycerol at $-80{ }^{\circ} \mathrm{C}$ were grown at $28{ }^{\circ} \mathrm{C}$ for $24 \mathrm{~h}$ on marine agar and then to log phase in marine broth 2216 (Difco Laboratories, Detroit, Mich.) by incubation at $28^{\circ} \mathrm{C}$. Overproduction of Artemia Hsp70 protein in $\mathrm{A}_{\text {native }}$ cells was stimulated by adding different doses of L-arabinose $(0,0.5$, 1,2 , and $4 \mathrm{mg} \mathrm{ml}^{-1}$ ) for a fixed time $(1 \mathrm{~h})$. Subsequently, L-arabinose at $0.5 \mathrm{mg} \mathrm{ml}^{-1}$, which gave the best induction in the dose-response experiment, was tested for different time intervals (1, 2, 3 and $4 \mathrm{~h}$ ) [18]. Maximum production of Artemia Hsp70 in $\mathrm{A}_{\text {native }}$ cells was obtained at $0.5 \mathrm{mg} \mathrm{ml}^{-1} \mathrm{~L}$-arabinose for $4 \mathrm{~h}$, as obtained for YS2 cells overproducing DnaK [13]. The respective bacteria after induction were transferred to sterile tubes, centrifuged at $2200 \times \mathrm{g}$ for $15 \mathrm{~min}$ at $28{ }^{\circ} \mathrm{C}$, suspended in filtered $(0.2 \mu \mathrm{m})$ autoclaved sea water, and fed immediately to Artemia larvae. Bacteria cell numbers were determined spectrophotometrically at $550 \mathrm{~nm}$ according to the McFarland standard (BioMerieux, Marcy L'Etoile, France), assuming that an optical density of 1.000 corresponds to $1.2 \times 10^{9}$ cells $\mathrm{ml}^{-1}$.

\subsection{Artemia and axenic hatching}

Axenic Artemia were obtained following decapsulation and hatching procedures as described by Marques et al. [19]. Briefly, Artemia cysts $(60 \mathrm{mg}$ ) originating from the Great Salt Lake, Utah, USA (EG ${ }^{\circledR}$ Type, batch 21452, INVE Aquaculture, Baasrode, Belgium) were hydrated in $9 \mathrm{ml}$ ofdistilled water for $1 \mathrm{~h}$. Sterile cysts and nauplii were obtained via decapsulation using $0.33 \mathrm{ml} \mathrm{NaOH} \mathrm{(32 \% )}$ and $5 \mathrm{ml} \mathrm{NaOCl}$ (50\%). During the reaction, $0.22 \mu \mathrm{m}$ filtered aeration was provided. All manipulations were carried out under a laminar flow hood and all necessary tools were previously autoclaved at $121^{\circ} \mathrm{C}$ for $20 \mathrm{~min}$. The decapsulation was stopped after about $2 \mathrm{~min}$ by adding $5 \mathrm{ml} \mathrm{Na}{ }_{2} \mathrm{~S}_{2} \mathrm{O}_{3}\left(10 \mathrm{~g} \mathrm{l}^{-1}\right)$. The aeration was then stopped and the decapsulated cysts were washed with filtered $(0.2 \mu \mathrm{m})$ and autoclaved artificial seawater containing $35 \mathrm{~g} 1^{-1}$ of Instant Ocean synthetic sea salt (Aquarium Systems, Sarrebourg, France). The cysts were re-suspended in a $50 \mathrm{ml}$ glass tube containing $30 \mathrm{ml}$ of filtered and autoclaved artificial seawater and incubated for $28 \mathrm{~h}$ (allowing the emerged nauplii to reach stage II in which they are able to ingest bacteria) on a rotor $(4 / \mathrm{min})$ at $28{ }^{\circ} \mathrm{C}$ with constant illumination (approximately 2000 lux). Groups of 30 nauplii were transferred to new sterile $50 \mathrm{ml}$ glass tubes that contained $30 \mathrm{ml}$ of filtered and autoclaved artificial seawater. The nauplii were incubated for $6 \mathrm{~h}$ with YS1, YS2 and $\mathrm{A}_{\text {native }}$ strains at $10^{7} \mathrm{cells} \mathrm{ml}^{-1}$. They were then challenged with $V$. campbellii at $10^{7}$ cells $\mathrm{ml}^{-1}$ for $36 \mathrm{~h}$. All manipulations were performed under a laminar flow hood in order to maintain sterility of the cysts and nauplii. The survival of Artemia was scored $36 \mathrm{~h}$ after the challenge. Each treatment was carried out in quintuplicate and each experiment was repeated twice to check the reproducibility.

\subsection{Methods used to verify axenicity of Artemia}

After hatching, the axenicity of the Artemia nauplli was verified by spread plating $100 \mu \mathrm{l}$ of the hatching water on Marine agar (Difco, Detroit, USA) followed by incubating at $28^{\circ} \mathrm{C}$ for 5 days [20]. Experiments started with non-sterile nauplii were discarded.

\subsection{Nutritional effect of the bacterial strains}

To examine the nutritional value of the induced and noninduced bacteria, axenically cultured Artemia larvae were fed once with approximately $10^{7}$ cells $\mathrm{ml}^{-1}$ of each bacterial strains (YS1, YS2, and $A_{\text {native }}$ ) without $V$. campbellii challenge. Swimming larvae were collected after two days, counted and fixed in lugol's solution. Survival percentage was calculated as described above. Individual length was ascertained by measuring fixed larvae with a dissecting microscope equipped with a drawing mirror, a digital plan measure and the software Artemia $1.0^{\circledR}$ (courtesy of Marnix Van Domme).

\subsection{Protein extraction, detection and analysis}

Bacteria were homogenized by rapid agitation with $0.1 \mathrm{~mm}$ diameter glass beads in cold buffer $\mathrm{K}(150 \mathrm{mM}$ sorbitol, $70 \mathrm{mM}$ potassium gluconate, $5 \mathrm{mM} \mathrm{MgCl}_{2}, 5 \mathrm{mM} \mathrm{NaH}_{2} \mathrm{PO}_{4}, 40 \mathrm{mM}$ HEPES, $\mathrm{pH}$ 7.4) [21] containing protease inhibitor cocktail (Catalogue \#P8465; Sigma-Aldrich, Inc.) at the highest recommended level. Subsequent to centrifugation at $2200 \times \mathrm{g}$ for $1 \mathrm{~min}$ at $4{ }^{\circ} \mathrm{C}$, supernatant protein concentrations were determined by the Bradford method [22] using bovine serum albumin as standard. Supernatant samples were then combined with loading buffer, vortexed, heated at $95{ }^{\circ} \mathrm{C}$ for $5 \mathrm{~min}$ and electrophoresed in 10\% SDS-PAGE gels, with each lane receiving equivalent amounts of protein. Gels were either stained with Coomassie Biosafe (BioRad Laboratories) or transferred to polyvinylidene fluoride membranes (BioRad Immun-Blot ${ }^{\mathrm{TM}}$ 
PVDF) for antibody probing. Membranes were incubated with blocking buffer [ $50 \mathrm{ml}$ of $1 \mathrm{x}$ phosphate buffered saline containing $0.2 \%(\mathrm{v} / \mathrm{v})$ Tween-20 and $5 \%(\mathrm{w} / \mathrm{v})$ bovine serum albumin] for $60 \mathrm{~min}$ at room temperature and then with monoclonal antibody $8 \mathrm{E} 2 / 2$, raised in mouse to DnaK, at the recommended dilution of 1:1000 (Stressgen Bioreagents) as primary antibody in case of YS1 and YS2 cells or with mouse monoclonal anti-Hsp70 antibody, clone 3A3 (Affinity BioReagents Inc., Golden, $\mathrm{CO}$ ) at the recommended dilution of 1:5000 in case of $A_{\text {native }}$ cells. Horseradish peroxidase conjugated donkey anti-mouse IgG was used as secondary antibody at the recommended dilution of 1:2500 (Affinity BioReagents Inc., Golden, CO) for all the bacterial cells. Detection was done with $0.7 \mathrm{mM}$ diaminobenzidine tetrahydrochloride dihydrate (DAB) in association with $0.01 \%(\mathrm{v} / \mathrm{v}) \mathrm{H}_{2} \mathrm{O}_{2}$ in $0.1 \mathrm{~m}$ Tris $-\mathrm{HCl}(\mathrm{pH} 7.6)$.

\subsection{Axenic Artemia rearing set-up for phenoloxidase (PO) assay}

The method for rearing axenic Artemia for PO assay was as described previously [23]. Briefly, A. franciscana cysts were decapsulated-disinfected as described in Section 2.3. After $28 \mathrm{~h}$ incubation at $28{ }^{\circ} \mathrm{C}$, swimming nauplii were collected, counted volumetrically ( 3 replicates) and thereafter transferred to sterile glass bottles $(1000 \mathrm{ml})$. The nauplii were incubated for $6 \mathrm{~h}$ with different induced or non-induced $E$. coli strains (as cited above) prior to $V$. campbellii $\left(10^{7}\right.$ cells $\mathrm{ml}^{-1}$ ) exposure. After $12 \mathrm{~h}$ exposure, $0.1 \mathrm{~g}$ of live nauplii was harvested (equal amount of animals for all treatments), rinsed in FASW and stored at $-80^{\circ} \mathrm{C}$. The experiment was repeated to obtain three samples per treatment for $\mathrm{PO}$ analysis.

\subsection{Preparation of crude enzyme extracts}

Sampling hemolymph from the microscopic Artemia larvae is a difficult task. Therefore, the entire larvae were used to prepare crude enzyme extracts $[23,24]$. Samples were homogenized in cold homogenizing mixture of $0.85 \% \mathrm{NaCl}-2.5 \mathrm{mM}$ EDTA and Triton-X $1 \%-10 \mathrm{mM} \mathrm{CaCl}_{2}(1: 1)$ so as to prepare $10 \%$ homogenate. The homogenates were placed at $4{ }^{\circ} \mathrm{C}$ for $36 \mathrm{~h}$ for enzyme extraction, thereafter centrifuged at $10,000 \times \mathrm{g}$ for $20 \mathrm{~min}$ at $4{ }^{\circ} \mathrm{C}$. The supernatants were used as crude enzyme extracts for PO assay.

\subsection{Assay of PO activity}

The PO activity of the enzyme extracts was determined according to the procedure described by Ashida et al. [25] with some modification. The enzyme extract $(100 \mu \mathrm{l})$ was added to the well of a 24-well microtitre plate to which $1 \mathrm{ml}$ of L-DOPA (substrate) dissolved in $100 \mathrm{mM}$ sodium acetate-citric acid buffer ( $\mathrm{pH}$ 7.1) containing $10 \mathrm{mM} \mathrm{CaCl}_{2}$ was added. The reactive mixture was incubated in dark conditions at $30{ }^{\circ} \mathrm{C}$ and monitored for changes in optical density (OD) at $490 \mathrm{~nm}$ for over $48 \mathrm{~h}$ using ELISA reader (Tecan, Männedorf, Switzerland). Background $\mathrm{OD}_{490}$ increment due to spontaneous non-enzymatic dopachrome production was assayed in wells without crude enzyme extract using only diluent mix and L-DOPA. Apparent PO activity was recorded as the change in absorbance over $48 \mathrm{~h}$ time interval and expressed in units as defined by Rojas-García et al. [23].

\subsection{Sequence comparisons}

Homology between the recombinant Artemia Hsp70 and DnaK proteins was determined by aligning the amino acid sequences of Artemia Hsp70 (GenBank accession no. AAL27404) and E. coli Dnak (GenBank accession no. NP_414555.1) using Clustal W multiplealignment method [26].

\subsection{Statistical analysis}

Survival data were arcsin transformed while individual length was either logarithmic or square root transformed to satisfy normality and homocedasticity requirements as necessary. Data were then subjected to one-way analysis of variances (ANOVA) followed by Duncan's multiple range tests using the statistical software Statistical Package for the Social Sciences (SPSS) version 14.0. to determine significant differences among treatments. Significance level was set at $P<0.05$. The experiments for testing the nutritional value of bacterial strains and resistance to Vibrio challenge, as described above in different sections, were performed twice with each replicate done in quintuplicate.

\section{Results}

\subsection{Optimizing L-arabinose dose and induction time for Artemia Hsp70 overproduction in E. coli}

To optimize the Hsp70 induction by L-arabinose, an expression experiment was set up by first incubating the $A_{\text {native }}$ cells with varying concentration of L-arabinose for $1 \mathrm{~h}$, and then by running a time course of expression. It could be shown that in the absence of arabinose some induction of Artemia Hsp70 occurred (Fig. 1B, control). Control strains, such as, induced or non-induced YS1, do not produce a protein recognised by monoclonal antibody $8 \mathrm{E} 2 / 2$, raised in mouse to DnaK (result not shown, see Sung et al. [13]). Already with $0.5 \mathrm{mg} \mathrm{ml}^{-1}$ arabinose and $1 \mathrm{~h}$ induction, maximal induction could be obtained. A single polypeptide of approximately $83 \mathrm{kDa}$ size was detected in the extract prepared from arabinoseinduced $A_{\text {native }}$ strain (Fig. $1 B$ and D). Similarly, DnaK was also upregulated in arabinose-induced YS2 strain, yielding a polypeptide of approximately $83 \mathrm{kDa}$ visible on Western blot probed with antibody to DnaK (result not shown, see Sung et al. [13]). The increase in molecular mass of approximately $13 \mathrm{kDa}$ in the induced $\mathrm{A}_{\text {native }}$ and YS2 strains, as compared with the normal mass of Hsp70 or DnaK, was because of the amino-terminal incorporation of thioredoxin encoded by the $\mathrm{TOPO}^{\circledR}$ cloning vector. Results also showed that longer induction ( $2 \mathrm{~h}$ or more) or higher arabinose concentration did not result in a substantial higher detectable amount of Artemia Hsp70 in the E. coli cells (Fig. 1B and D). For that the effect of feeding E. coli strains overproducing Artemia Hsp70 was investigated first (Tables 1 and 2) Secondly, the effect of feeding E. coli strains overproducing DnaK or Artemia Hsp70 was directly compared (Table 3). As can be seen, a significant $(P<0.01)$ increase in the survival (compared with the control) was recorded during the challenge tests when Artemia larvae were fed with $A_{\text {native }}$ strain induced with L-arabinose in the range of $0.5-4.0 \mathrm{mg} \mathrm{ml}^{-1}$, with maximum protection at the lowest L-arabinose concentration, however, not significantly $(P>0.05)$ different from the others (Table 1, Experiment 1). But in the second experimental run inducing $E$. coli with a higher concentration of arabinose ( 2 or $4 \mathrm{mg} \mathrm{ml}^{-1}$ ) resulted in a lower Artemia survival with respect to the lower arabinose concentrations $\left(0.5\right.$ and $\left.1 \mathrm{mg} \mathrm{ml}^{-1}\right)$, yet the survival was still significantly $(P<0.01)$ higher than in the control (Table 1 , experiment 2). Using $0.5 \mathrm{mg} \mathrm{ml}^{-1}$ arabinose, an induction period of $1 \mathrm{~h}$ was sufficient to confer some protection against pathogenic $V$. campbellii. The protection, however, was maximum and significantly $(P<0.05)$ higher after an induction period of $4 \mathrm{~h}$ (Table 2 ).

\subsection{Survival of vibrio-challenged Artemia fed homologous or heterologous Hsp70 proteins}

In the second set of in vivo tests, the effect of feeding induced and non-induced E. coli on the survival of Artemia either challenged or 
A

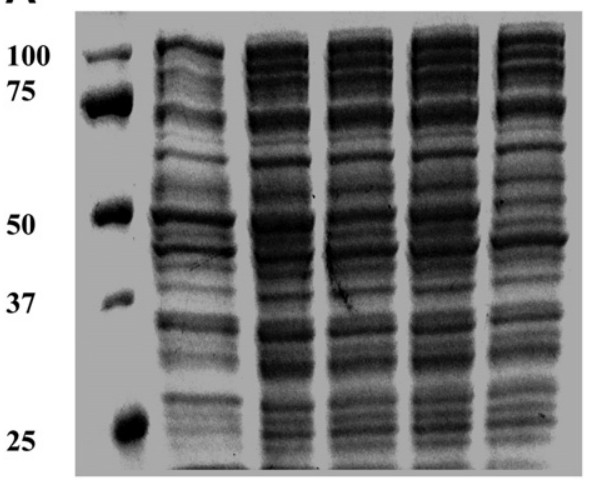

B

100
75
C

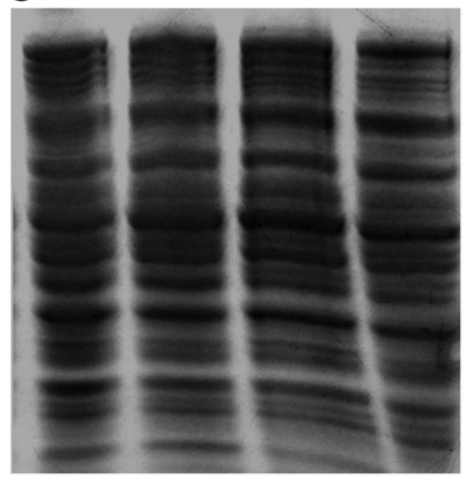

D

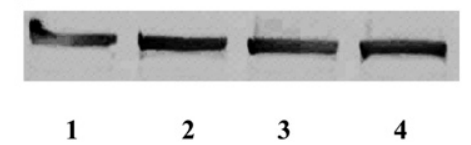

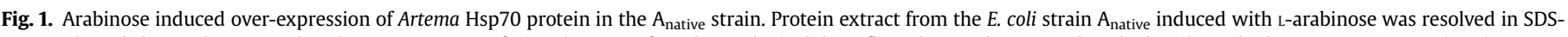

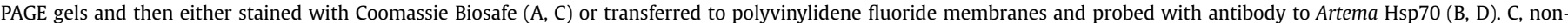

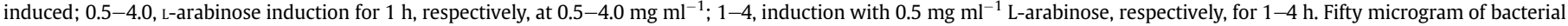
protein was loaded in each lane. Molecular mass standards (M) in kDa are on the left.

not with $V$. campbellii was investigated. The survival of the non-challenged nauplii fed either induced or non-induced $E$. coli cells (YS1, YS2 or $A_{\text {native }}$ cells) did not differ significantly $(P>0.05)$ among each other (Table 3$)$. In contrast, a significant $(P<0.001)$ difference among the challenged groups was noted. Survival of Artemia nauplii fed either induced or non-induced strain YS1 was low upon challenge with $V$. campbellii, results similar to those obtained with noninduced YS2 and Anative (Table 3). However, a significantly $(P<0.001)$ higher survival was obtained when arabinose-induced YS2 or $A_{\text {native }}$ strains were provided to challenged nauplii in comparison to challenged nauplii supplied with non-induced $E$. coli cells. Comparison between the challenged groups fed either induced YS2 or $A_{\text {native }}$ cells showed no significant differences $(P<0.05)$. The second experiment (Table 3, Experiment 2$)$ conducted to check the reproducibility showed similar results.

\subsection{Nutritional effect of the bacterial strains}

As the susceptibility of Artemia to pathogenic $V$. campbellii depends on the quality of feed fed [27], a test was performed by feeding induced and non-induced bacterial strains to Artemia in order to examine their nutritional value. Artemia nauplii fed with E. coli had significantly $(P<0.05)$ higher survival and length

Table 1

Percentage survival of Artemia nauplii after 36 h challenge with Vibrio campbellii LMG21363.

\begin{tabular}{llr}
\hline $\begin{array}{l}\text { L-arabinose } \\
\left(\mathrm{mg} \mathrm{ml}^{-1}\right)\end{array}$ & \multicolumn{2}{l}{ Survival $(\%)$} \\
\cline { 2 - 3 } & Experiment 1 & Experiment 2 \\
\hline 0 & $78.0 \pm 0.8^{\mathrm{b}}$ & $62.7 \pm 4.5^{\mathrm{c}}$ \\
0.5 & $86.7 \pm 1.8^{\mathrm{a}}$ & $96.0 \pm 2.7^{\mathrm{a}}$ \\
1 & $86.0 \pm 1.2^{\mathrm{a}}$ & $100.0 \pm 5.3^{\mathrm{a}}$ \\
2 & $86.7 \pm 1.8^{\mathrm{a}}$ & $76.0 \pm 3.4^{\mathrm{b}}$ \\
4 & $84.7 \pm 0.8^{\mathrm{a}}$ & $78.7 \pm 3.9^{\mathrm{b}}$ \\
\hline
\end{tabular}

Data are represented as mean \pm standard error $(n=5)$. Different superscripts in the same column represent significance difference $(P<0.01)$. The $A_{\text {native cells were }}$ induced with different concentration of L-arabinose for $1 \mathrm{~h}$. Artemia nauplii were fed once with $A_{\text {native }}$ cells at $10^{7}$ cells $\mathrm{ml}^{-1}$ and incubated for $6 \mathrm{~h}$ before challenge with V. campbellii LMG21363 for $36 \mathrm{~h}$. compared with the non-fed Artemia (Table 4). However, the number of live larvae and the length among the different groups fed either induced or non-induced bacterial strains was not significantly $(P<0.05)$ different.

\subsection{Phenoloxidase activity}

To elucidate the role Hsp70 proteins in the host defence against V. campbellii, apparent phenoloxidase (PO) activity was determined in the Vibrio challenged Artemia, and this showed that the PO activity varied among different treatments (Fig. 2). The level of PO activity in the group fed either arabinose-induced YS2 or $A_{\text {native }}$ strains was significantly $(P<0.05)$ higher than those fed either non-induced YS2 or $A_{\text {native }}$ strains. Artemia fed either induced or non-induced YS1 strain had a marked $(P<0.05)$ decrease in PO activity compared to those fed induced YS2 or $A_{\text {native }}$ strains, however, they were significantly $(P<0.05)$ higher than that of the group fed non-induced YS2 strain.

\subsection{Sequence comparison of Artemia and E. coli Hsp70 proteins}

The amino acid sequence of Artemia Hsp70 protein showed a high degree of identity to that of the Hsp70 protein of E. coli

Table 2

Percentage survival of Artemia nauplii after 36 h challenge with Vibrio campbellii LMG21363.

\begin{tabular}{lll}
\hline Induction time $(\mathrm{h})$ & \multicolumn{2}{l}{ Survival $(\%)$} \\
\cline { 2 - 3 } & Experiment 1 & Experiment 2 \\
\hline 0 & $40.0 \pm 3.7^{\mathrm{c}}$ & $32.0 \pm 4.0^{\mathrm{c}}$ \\
1 & $51.3 \pm 5.0^{\mathrm{b}}$ & $46.7 \pm 3.2^{\mathrm{b}}$ \\
2 & $53.3 \pm 1.5^{\mathrm{b}}$ & $53.3 \pm 3.8^{\mathrm{b}}$ \\
3 & $51.3 \pm 2.3^{\mathrm{b}}$ & $52.0 \pm 5.3^{\mathrm{b}}$ \\
4 & $68.0 \pm 1.7^{\mathrm{a}}$ & $70.0 \pm 3.3^{\mathrm{a}}$ \\
\hline
\end{tabular}

Data are represented as mean \pm standard error $(n=5)$. Different superscripts in the same column represent significance difference $(P<0.01)$. The $A_{\text {native cells were }}$ induced with L-arabinose at a concentration of $0.5 \mathrm{mg} \mathrm{ml}^{-1}$ for different durations $(0,1,2,3$, and $4 \mathrm{~h})$. Artemia nauplii were fed once with $A_{\text {native }}$ cells at $10^{7}$ cells ml $^{-1}$ and incubated for $6 \mathrm{~h}$ before challenge with $V$. campbellii LMG21363 for 36h. 
Table 3

Percentage survival of Artemia nauplii after 36 h challenge with Vibrio campbellii LMG21363.

\begin{tabular}{lll}
\hline Treatments & \multicolumn{2}{l}{ Survival (\%) } \\
\cline { 2 - 3 } & Experiment 1 & Experiment 2 \\
\hline YS1 (-) & $82.7 \pm 2.2^{\mathrm{ab}}$ & $78.0 \pm 3.3^{\mathrm{c}}$ \\
YS1 (-) + VC & $41.3 \pm 2.7^{\mathrm{d}}$ & $36.7 \pm 2.4^{\mathrm{f}}$ \\
YS1 (+) & $81.3 \pm 2.7^{\mathrm{a}}$ & $80.0 \pm 2.4^{\mathrm{c}}$ \\
YS1 (+) + VC & $43.3 \pm 3.9^{\mathrm{d}}$ & $38.7 \pm 3.4^{\mathrm{f}}$ \\
YS2 (-) & $84.7 \pm 4.9^{\mathrm{ab}}$ & $82.0 \pm 4.0^{\mathrm{bc}}$ \\
YS2 (-) + VC & $50.0 \pm 3.8^{\mathrm{d}}$ & $54.0 \pm 3.7^{\mathrm{e}}$ \\
YS2 (+) & $90.7 \pm 2.7^{\mathrm{ab}}$ & $90.7 \pm 0.7^{\mathrm{ab}}$ \\
YS2 (+) + VC & $70.0 \pm 3.8^{\mathrm{c}}$ & $68.0 \pm 3.4^{\mathrm{d}}$ \\
$\mathrm{A}_{\text {native }}(-)$ & $90.7 \pm 2.4^{\mathrm{ab}}$ & $83.3 \pm 5.1^{\mathrm{abc}}$ \\
$\mathrm{A}_{\text {native }}(-)+$ VC & $41.3 \pm 3.4^{\mathrm{d}}$ & $35.3 \pm 3.3^{\mathrm{f}}$ \\
$\mathrm{A}_{\text {native }}(+)$ & $92.0 \pm 2.0^{\mathrm{a}}$ & $92.7 \pm 1.9^{\mathrm{a}}$ \\
$\mathrm{A}_{\text {native }}(+)+$ VC & $62.0 \pm 3.7^{\mathrm{c}}$ & $59.3 \pm 2.4^{\mathrm{de}}$ \\
\hline
\end{tabular}

Data are represented as mean \pm standard error $(n=5)$. Different superscripts in the same column represent significance difference $(P<0.001)$. The bacterial strains YS1 (a Hsp70 non-producer), YS2 (a DnaK producer after arabinose induction), and A native (an Artemia Hsp70 producer after arabinose induction) were either induced $(+)$ or non-induced $(-)$ with L-arabinose at concentration of $0.5 \mathrm{mg} \mathrm{ml}^{-1}$ for $4 \mathrm{~h}$. Artemia larvae were fed once with the bacterial strains at $10^{7}$ cells $\mathrm{ml}^{-1}$ and incubated for $6 \mathrm{~h}$ before challenge with $V$. campbellii (VC) for $36 \mathrm{~h}$.

(Fig. 3). Identity between these two proteins was higher in the peptide-binding domain (59.6\%), compared to the N-terminal ATPase domain (48.8\%) and the C-terminal lid domain (19.4\%) (Table 5). The overall identity of the two proteins was in the range of $45.8 \%$

\section{Discussion}

A substantial sequence homology exists between equivalent Hsp family members derived either from prokaryotes or eukaryotes $[14,28]$. Hence it was assumed that these Hsps would have a high degree of functional conservation, also with respect to their protective capacity in a Vibrio challenge test. In order to document this hypothesis, gnotobiotically grown Artemia franciscana was used to test the efficacy of prokaryotic (E. coli DnaK) and eukaryotic (Artemia Hsp70) Hsp70 proteins overproduced in E. coli in protecting Artemia nauplii against Vibrio challenge. Working in gnotobiotic circumstances facilitates the interpretation of the results in terms of a cause effect relationship. In this study, strain YS2 was used as the source of prokaryotic Hsp70. This strain was

Table 4

Percentage survival and individual length ( $\mathrm{mm}$ ) of Artemia after $48 \mathrm{~h}$ of feeding Larabinose induced or non-induced $E$. coli strains.

\begin{tabular}{|c|c|c|c|c|}
\hline \multirow[t]{2}{*}{ Treatments } & \multicolumn{2}{|c|}{ Experiment 1} & \multicolumn{2}{|l|}{ Experiment 2} \\
\hline & Survival & $\begin{array}{l}\text { Individual } \\
\text { length }\end{array}$ & Survival & $\begin{array}{l}\text { Individual } \\
\text { length }\end{array}$ \\
\hline Non-fed Artemia & $70.0 \pm 1.5^{\mathrm{b}}$ & $0.66 \pm 0.03^{b}$ & $68.0 \pm 0.8^{c}$ & $0.66 \pm 0.03^{b}$ \\
\hline YS1 (+) & $83.3 \pm 2.8^{a}$ & $0.81 \pm 0.02^{\mathrm{a}}$ & $78.0 \pm 4.3^{b}$ & $0.79 \pm 0.03^{\mathrm{a}}$ \\
\hline YS1 (-) & $81.3 \pm 4.0^{\mathrm{a}}$ & $0.81 \pm 0.02^{\mathrm{a}}$ & $82.0 \pm 3.1^{\mathrm{ab}}$ & $0.76 \pm 0.03^{a}$ \\
\hline YS2 (-) & $88.0 \pm 2.5^{a}$ & $0.78 \pm 0.03^{a}$ & $80.7 \pm 4.1^{\mathrm{ab}}$ & $0.76 \pm 0.02^{\mathrm{a}}$ \\
\hline YS2 (+) & $89.3 \pm 3.7^{\mathrm{a}}$ & $0.76 \pm 0.04^{a}$ & $88.7 \pm 3.6^{\mathrm{a}}$ & $0.75 \pm 0.01^{\mathrm{a}}$ \\
\hline$A_{\text {native }}(+)$ & $85.3 \pm 3.8^{a}$ & $0.83 \pm 0.02^{\mathrm{a}}$ & $84.0 \pm 1.3^{a b}$ & $0.81 \pm 0.02^{\mathrm{a}}$ \\
\hline$A_{\text {native }}(-)$ & $82.0 \pm 4.4^{\mathrm{a}}$ & $0.81 \pm 0.03^{a}$ & $77.3 \pm 1.3^{\mathrm{b}}$ & $0.77 \pm 0.02^{\mathrm{a}}$ \\
\hline
\end{tabular}

Data are represented as mean \pm standard error $(n=5)$. Different superscripts in the same column represent significance difference $(P<0.05)$. The bacterial strains YS1 (a Hsp70 non-producer), YS2 (a DnaK producer after arabinose induction), and $\mathrm{A}_{\text {native }}$ (an Artemia Hsp70 producer after arabinose induction) were either noninduced (-) or induced (+) with L-arabinose at concentration of $0.5 \mathrm{mg} \mathrm{ml}^{-1}$ for $4 \mathrm{~h}$. Artemia were fed with these bacteria strains at $10^{7}$ cells $\mathrm{ml}^{-1}$ and following 2 days incubation, the number and length of the live larvae were determined. Artemia that were not fed was used as control.

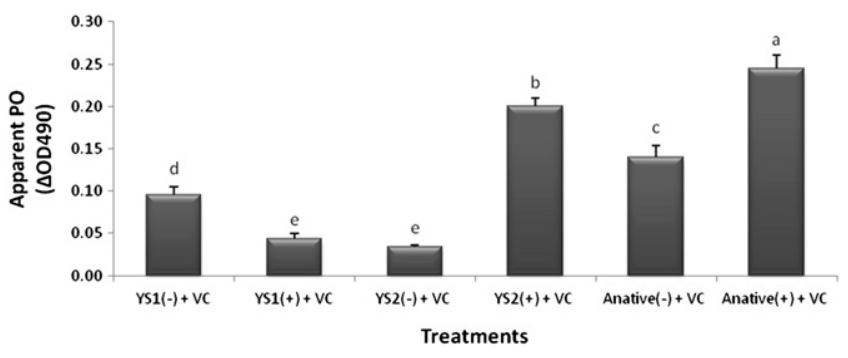

Fig. 2. Apparent PO activity Artemia. Data represents the mean of three independent experiments. Error bars with different alphabet letters indicate significant difference $(P<0.05)$. The bacterial strains YS1 (a Hsp70 non-producer), YS2 (a DnaK producer after arabinose induction), and $A_{\text {native }}$ (an Artemia Hsp70 producer after arabinose induction) were either induced $(+)$ or non-induced (-) with L-arabinose at concentration of $0.5 \mathrm{mg} \mathrm{ml}^{-1}$ for $4 \mathrm{~h}$. Artemia larvae were fed once with the bacterial strains at $10^{7}$ cells $\mathrm{ml}^{-1}$ and incubated for $6 \mathrm{~h}$ before challenge with V. campbellii (VC) for $12 \mathrm{~h}$.

developed in our previous study [13] and is producing DnaK by arabinose induction. As a source of eukaryotic Hsp70 protein, the strain $A_{\text {native }}$ was constructed in this study. This strain was developed in a similar fashion [13], except that Artemia Hsp70 cDNA was cloned into the same plasmid pBAD.

A problem in studying the effect of recombinant proteins produced in E. coli is the possibility that the observed protective effects are caused by lipopolysaccharide $[29,30]$. To accommodate for this possibility, the strain YS1 (non-induced or induced) carrying the empty cloning vector was used as control.

Results of our in vivo challenge test revealed that arabinoseinduced YS2 and $A_{\text {native }}$ strains were more potent and efficacious than their non-induced counterparts in safeguarding Artemia against $V$. campbellii. Furthermore, results also showed that both the induced strains conferred protection to Vibrio-challenged Artemia to a similar extent, consistent with the capacity of the YS2 or $A_{\text {native }}$ strains to produce respective Hsp70 proteins upon arabinose addition. In contrast, the arabinose-induced or noninduced YS1 strain, a Hsp70 non-producer upon arabinose addition, was found to be the least effective of these three bacterial strains in conferring protection to Artemia. This strongly indicates that both Artemia Hsp70 and DnaK are responsible for conferring protection to the Vibrio-challenged Artemia, and that their protective capacity is caused by the recombinant intracellular Hsp70 proteins and not the result of lipopolysaccharide exposure or any other E. coli-bound cellular material. Furthermore, our result also showed that the nutritional value of the induced $E$. coli strains was not significantly different from that of the non-induced strains, in accordance to the findings of Sung et al. [13]. This observation further substantiates the abovementioned conclusion that the recombinant Hsp70 proteins (and not the bacterial cells) were responsible for protecting Artemia against bacterial infection and that the difference in Artemia protection were not due to difference in the nutritional value of the non-induced versus induced strains.

In a previous study [12], it was found that Artemia was protected against $V$. campbellii after a non-lethal heat shock, resulting into an increased Hsp70 expression. That research suggested that these two phenomena were linked. In this paper, we extend this work basically showing that offering Artemia its homologous Hsp70 protein through the feed also results into a protective effect, establishing a much closer casual link between Hsp70 and protection against $V$. campbellii. Obviously, the route of exposure is completely different, raising questions about how the observed effects are brought about for instance at the immunological level. The molecular mechanisms involved in such a protective effect is not yet clearly known, however, could be attributed to strong 


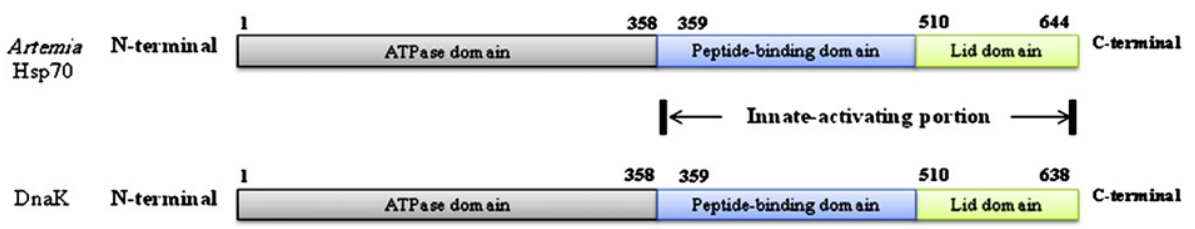

Fig. 3. Scheme of the three functionally distinct domains of Artemia Hsp70 and DnaK proteins (adapted from Todryk et al. [17] and Kabani and Martineau [47]).

induction of immunological responses in Artemia by these proteins as elevated activity of PO enzyme, one of the most important defence mechanisms in crustaceans [31], in groups fed arabinoseinduced YS2 and $A_{\text {native }}$ strains was recorded. The occurrence and modulation of other immunological responses such as, nitric oxide synthase, superoxide dismutase, lysozymes and others by these Hsp70 proteins might also occur in challenged Artemia, however, it needs to be demonstrated. In line with our results, there is evidence that Hsps modulate immune and inflammatory responses in other animals [13,32-35]. For instance, application of Hsps in vitro induced phagocytes and granulocytes to release reactive oxygen species, cationic peptides, lysozyme and cytokines [36,37]. Additionally, macrophages and neutrophils were stimulated to produce nitric oxide synthase [38], nitric oxide [39], tumour necrosis factor$\alpha$, interleukin (IL)-1 $\beta$ and IL-6 [39-41], all extracellular suppressors of infection. Hsps also activate Toll like receptors, which transduce inflammatory signals to innate immune cells and promote resistance against disease and infections [42,43]. Furthermore, exogenous administration of Hsps up-regulates two major macrophage/ monocyte differentiation markers [44], all of which suppress infection.

The primary structure of the bacterial Hsp70 protein, DnaK, is very similar to its eukaryotic counterpart and consists of three functionally distinct domains: an N-terminal 44-kDa ATPase domain, an 18-kDa peptide-binding domain, and a C-terminal 10$k D a$ lid domain $[5,45]$. Several studies demonstrated that the immune stimulating functions of Hsp70 reside in the C-terminal portion (amino acid 359-610, Fig. 3), particularly in the 18-kDa peptide binding domain (amino acid 359-494) [5,46]. Comparison of the peptide sequence of the two Hsp70 proteins demonstrate a high degree of homology, particularly in the peptide-binding domain (see Table 5), suggesting that this part of the protein might be responsible for the observed effects.

Taken together, the results demonstrate that both Artemia Hsp70 and DnaK, in qualitative terms, appeared to be equally efficient in protecting Artemia in a Vibrio challenge assay, when offered to Artemia in E. coli overproducing cells. In quantitative terms, it is not possible to state which molecule protects Artemia better, as it is not possible to quantify the amount of Hsp70 or DnaK ingested by Artemia. The latter is due to various reasons. Firstly, different antibodies were used to detect the DnaK and Hsp70 antigens possibly resulting in a different dose-response relationship in the western blot. Secondly, the actual ingestion of $E$. coli cells was not measured. In the future, detailed research has to be focused on this aspect, also revealing the dose-response relationship at the immunological level, using for example established markers such as phenoloxidase expression or activity [31].

\section{Table 5}

Percentage of identity and similarity between different domains of Artemia Hsp70 and E. coli-equivalent Dnak proteins.

\begin{tabular}{lll}
\hline Domains & Identity (\%) & Similarity (\%) \\
\hline ATPase domain & 48.8 & 78.2 \\
Peptide-binding domain & 59.6 & 83.3 \\
Lid domain & 19.4 & 52.9 \\
\hline
\end{tabular}

\section{Acknowledgements}

This study was supported by a doctoral grant to the first author from developing countries (Bijzonder Onderzoeksfonds) by Ghent University, Belgium. We thank the technical staffs of Lab of Aquaculture and Artemia Reference Centre, Ghent University for their assistance in carrying out various analyses during the research work. The projects entitled 'Hsp70 in gastheer-microbiele interacties (1.5.092.09.N.00)' and 'Probiontinduced functional responses in aquatic organisms (G.0.491.08.N.10)' funded by Research Foundation - Flanders, Belgium were highly acknowledged.

\section{References}

[1] Subasinghe RP, Bondad-Reantaso MG, McGladdery SE. Aquaculture development, health and wealth. In: Subasinghe RP, Bueno P, Phillips MJ, Hough C, McGladdery SE, Arthur JR, editors. Aquaculture in the third millennium. Technical proceedings of the conference on aquaculture in the third millennium. Bangkok: NACA; 2001. p. 167-91.

[2] Subasinghe R. Fish health and quarantine. Review of the State of World Aquaculture, FAO Fisheries Circular, vol. 886. Rome, Italy: Food and Agriculture Organisation of the United Nations; 1997. pp. 45-9.

[3] Smith VJ, Brown JH, Hauton C. Immunostimulation in crustaceans: does it really protect against infection? Fish Shellfish Immunol 2003;15:71-90.

[4] Kumaraguru U, Gouffon Jr CA, Ivey III RA, Rouse BT, Bruce BD. Antigenic peptides complexed to phylogenically diverse Hsp70s induce differential immune responses. Cell Stress Chaperones 2003;8:134-43.

[5] Wang Y, Whittall T, McGowan E, Younson J, Kelly C, Bergmeier LA, et al. Identification of stimulating and inhibitory epitopes within the heat shock protein 70 molecule that modulate cytokine production and maturation of dendritic cells. J Immunol 2005;174:3306-16.

[6] Srivastava P. Roles of heat heat-shock proteins in innate and adaptive immunity. Nat Rev Immunol 2002;2:185-94.

[7] Robert J. Evolution of heat shock protein and immunity. Dev Comp Immuno 2003:27:449-64.

[8] Stewart GR, Young DB. Heat-shock proteins and the host-pathogen interaction during bacterial infection. Curr Opin Immunol 2004;16:506-10.

[9] Wang Z, Wu Z, Jian J, Lu Y. Cloning and expression of heat shock protein 70 gene in the haemocytes of pearl oyster (Pinctada fucata, Gould 1850) responding to bacterial challenge. Fish Shellfish Immunol 2009;26:639-45.

[10] Żmijewski MA, Macario AJL, Lipińska B. Functional similarities and differences of an archaeal Hsp70 (DnaK) stress protein compared with its homologue from the bacterium Escherichia coli. J Mol Biol 2004;336:539-49.

[11] Morimoto RI, Jurivich DA, Kroger PE, Mathur SK, Murphy SP, Nakai A, et al. Regulation of heat shock gene transcription by a family of heat shock factors. In: Morimoto RI, Tissières A, Georgopoulos C, editors. The Biology of heat shock proteins and molecular chaperones. Cold Spring Harbor: ColdSpring Harbor Laboratory Press; 1994. p. 417-55.

[12] Sung YY, Van Damme EJM, Sorgeloos P, Bossier P. Non-lethal heat shock protects gnotobiotic Artemia franciscana larvae against virulent Vibrios. Fish Shellfish Immunol 2007;22:318-26.

[13] Sung YY, Dhaene T, Defoirdt T, Boon N, MacRae TH, Sorgeloos P, et al. Ingestion of bacteria overproducing DnaK attenuates Vibrio infection of Artemia franciscana larvae. Cell Stress Chaperones 2009;14:603-9.

[14] Pockley AG, Muthana M, Calderwood SK. The dual immunoregulatory roles of stress proteins. Trends Biochem Sci 2007;33:71-9.

[15] Lewthwaite J, George R, Lund PA, Poole S, Tormay P, Sharp L, et al. Rhizobium leguminosarum chaperonin 60.3 , but not chaperonin 60.1 , induces cytokine production by human monocytes: activity is dependent on interaction with cell surface CD14. Cell Stress Chaperones 2002;7:130-6.

[16] Lewthwaite JC, Coates ARM, Tormay P, Singh M, Mascagni P, Poole S, et al. Mycobacterium tuberculosis chaperonin 60.1 is a more potent cytokine stimulator than chaperonin 60.2 (hsp 65) and contains a CD14-binding domain. Infect Immun 2001;69:7349-55.

[17] Todryk SM, Goughy MJ, Pockley AG. Facets of heat shock protein 70 show immunotherapeutic potential. Immunology 2003;110:1-9. 
[18] Nishihara K, Kanemori M, Yanagi H, Yura T. Overexpression of trigger factor prevents aggregation of recombinant proteins in Escherichia coli. Appl Environ Microbiol 2000;66:884-9.

[19] Marques A, Dhont J, Sorgeloos P, Bossier P. Evaluation of different yeast cell wall mutants and microalgae strains as feed for gnotobiotically-grown brine shrimp Artemia franciscana. J Exp Mar Biol Ecol 2004;312:115-36.

[20] Baruah K, Cam DTV, Dierckens K, Wille M, Defoirdt T, Sorgeloos P, et al. In vivo effects of single or combined $\mathrm{N}$-acyl homoserine lactone quorum sensing signals on the performance of Macrobrachium rosenbergii larvae. Aquaculture 2009;288:233-8.

[21] Clegg JS, Jackson SA, Hoa NV, Sorgeloos P. Thermal resistance, developmental rate and heat shock proteins in Artemia franciscana, from San Francisco Bay and southern Vietnam. J Exp Mar Biol Ecol 2000;252:85-96.

[22] Bradford MM. A rapid and sensitive method for the quantitation of microgram quantities of protein utilizing the principle of protein-dye binding. Anal Biochem 1976;72:248-54.

[23] Rojas-García CR, Sorgeloos P, Bossier P. Phenoloxidase and trypsin in germfree larvae of Artemia fed with cooked unicellular diets: examining the alimentary and protective effects of putative beneficial bacterium, yeast and microalgae against vibriosis. J Exp Mar Biol Ecol 2009;381:90-7.

[24] Misra C, Das B, Pradhan J, Pattnaik P, Sethi S, Mukherjee S. Changes in lysosomal enzyme activity and protection against Vibrio infection in Macrobrachium rosenbergii (De Man) post larvae after bath immunostimulation with $\beta$-glucan. Fish Shellfish Immunol 2004;17:389-95.

[25] Ashida M, Ishizaki Y, Iwahana H. Activation of prophenoloxidase by bacteria cell walls or $\beta-1,3$ glucans in plasma of the silkworm Bombyx mori. Biochem Biophys Res Commun 1983;113:562-8.

[26] Thompson JD, Higgins DG, Gibson TJ. Clustal W: Improving the sensitivity of progressive multiple sequence alignment through sequence weighting, position-specific gap penalties and weight matrix choice. Nucleic Acids Res 1994;22:4673-80.

[27] Marques A, Dinh T, Ioakeimidis C, Huys G, Swings J, Verstraete W, et al. Effects of bacteria on Artemia franciscana cultured in different gnotobiotic environments. Appl Environ Microbiol 2005;71:4307-17.

[28] Lamb JR, Bal V, Mendez-Samperio P, Mehiert A, So A, Rothbard J, et al. Stress proteins might provide a link between the immune response to infection and autoimmunity. Int Immunol 1989;1:191-6.

[29] Wallin RPA, Lundqvist A, Moré SH, von Bonin A, Kiessling R, Ljunggren HG. Heat-shock proteins as activators of the innate immune system. Trends Immunol 2002;23:130-5.

[30] Maguire M, Poole S, Coates ARM, Tormay P, Wheeler-Jones C, Henderson B. Comparative cell signalling activity of ultrapure recombinant chaperonin 60 proteins from prokaryotes and eukaryotes. Immunology 2005;115:231-8.

[31] Liu H, Jiravanichpaisal P, Cerenius L, Lee BL, Söderhäll I, Söderhäll K. Phenoloxidase is an important component of the defense against Aeromonas hydrophila infection in a crustacean, Pacifastacus leniusculus. J Biol Chem 2007;282:33593-8.
[32] Lewthwaite JC, Clarkin CE, Coates ARM, Poole S, Lawrence RA, WheelerJones CPD, et al. Highly homologous Mycobacterium tuberculosis chaperonin 60 proteins with differential CD14 dependencies stimulate cytokine production by human monocytes through cooperative activation of p38 and ERK1/2 mitogen-activated protein kinases. Int Immunopharmacol 2007;7:230-40.

[33] Coelho V, Broere F, Binder RJ, Shoenfeld Y, Moudgil KD. Heat-shock proteins: inflammatory versus regulatory attributes. Cell Stress Chaperones 2008; 13:119-25.

[34] Ryckaert J, Pasmans F, Tobback E, Duchateau L, Decostere A, Haesebrouck F, et al. Heat shock proteins protect platyfish (Xiphophorus maculatus) from Yersinia ruckeri induced mortality. Fish Shellfish Immunol 2010;28:228-31.

[35] Sung YY, Ashame MF, Chen S, MacRae TH, Sorgeloos P, Bossier P. Feeding Artemia franciscana (Kellogg) larvae with bacterial heat shock protein, protects from Vibrio campbellii infection. J Fish Dis 2009;32:675-85.

[36] Jacquier-Sarlin MR, Fuller K, Dinh-Xuan AT, Richard MJ, Polla BS. Protective effects of hsp70 in inflammation. Experientia 1994;50:1031-8.

[37] Basu N, Todgham AE, Ackerman PA, Bibeau MR, Nakano K, Schulte PM, et al. Heat shock protein genes and their functional significance in fish. Gene 2002;295:173-83.

[38] Panjwani NN, Popova L, Srivastava PK. Heat shock proteins gp96 and hsp70 activate the release of nitric oxide by APCs. J Immunol 2002;168:2997-3003.

[39] Campisi J, Fleshner M. The role of extracellular Hsp72 in acute stress-induced potentiation of innate immunity in physically active rats. J Appl Physiol 2003;94:43-52.

[40] Asea A, Kraeft SK, Kurt-Jones EA, Stevenson MA, Chen LB, Finberg RW, et al. HSP70 stimulates cytokine production through a CD14-dependant pathway, demonstrating its dual role as a chaperone and cytokine. Nat Med 2000; 6:435-42.

[41] Johnson JD, Fleshner M. Releasing signals, secretory pathways, and immune function of endogenous extracellular heat shock protein 72 . J Leukoc Biol 2006:79:425-34.

[42] Asea A, Rehli M, Kabingu E, Boch JA, Bare O, Auron PE, et al. Novel signal transduction pathway utilized by extracellular HSP70: role of Toll-like receptor (TLR) 2 and TLR4. J Biol Chem 2002;277:15028-34.

[43] Vabulas RM, Ahmad-Nejad P, Ghose S, Kirschning CJ, Issels RD, Wagner H. HSP70 as endogenous stimulus of the Toll/interleukin-1 receptor signal pathway. J Biol Chem 2002;277:15107-12.

[44] Edgington S. Therapeutic applications of heat shock proteins. J Biotechnol 1995; 13:1442-4

[45] Zhu X, Zhao X, Burkholder WF, Gragerov A, Ogata CM, Gottesman ME, et al. Structural analysis of substrate binding by the molecular chaperone DnaK. Science 1996;272:1606-14.

[46] MacAry PA, Javid B, Floto RA, Smith KGC, Oehlmann KGC, Singh M, et al. HSP70 peptide binding mutants separate antigen delivery from dendritic cell stimulation. Immunity 2004;20:95-106.

[47] Kabani M, Martineau CN. Multiple Hsp70 isoforms in the eukaryotic cytosol: mere redundancy or functional specificity? Curr Genom 2008;9:338-48. 